\title{
Quality of life for older patients with cancer: a review of the evidence supporting melatonin use
}

\author{
Angeline Ginzac ${ }^{1,2,3}$ (1) Sophie Dubois ${ }^{4}$. Marie-Odile Hager ${ }^{4,5} \cdot$ Fabrice Kwiatkowski $^{2}$. Judith Passildas ${ }^{1,2,3}$. \\ Julian Biau ${ }^{1,6} \cdot$ Catherine Abrial $^{1,2,3} \cdot$ Marie-Ange Mouret-Reynier $^{1,4} \cdot$ Emilie Thivat $^{1,2,3} \cdot$ Xavier Durando $^{1,2,3,4}$
}

Received: 7 January 2020 / Accepted: 7 March 2020 / Published online: 31 March 2020

(c) The Author(s) 2020

\begin{abstract}
Purpose The proportion of older populations living with cancer is on the increase. Maintaining or improving their quality of life (QoL) has become an important goal in the treatment of cancer and has become an endpoint in clinical trials. Melatonin regulates a wide variety of physiological functions and is involved in the initiation of sleep and the improvement of QoL. With age, the secretion of melatonin decreases and could lead to a deterioration in QoL.

Methods Literature searches were conducted using the PubMed database. The search terms and derivatives of "metastatic cancer", "older patients", "quality of life" and "melatonin" were used. Titles and abstracts were screened to identify whether studies were relevant for full-text screening.

Results There is major concern about the symptoms older cancer patients encounter during treatment because they can impact their QoL. Melatonin supplementation presents several benefits for older patients: improvement in survival, decrease in symptoms induced by cancer and cancer treatment, and also improvements in quality of life.

Conclusion It therefore seems appropriate to study the impact of melatonin supplementation during cytotoxic therapy on QoL among elderly patients with metastatic cancer. The use of melatonin as a therapeutic strategy seems particularly suitable for elderly patients, a population known to secrete significantly less melatonin. However, to date, no studies have been conducted in this population.
\end{abstract}

Keywords Melatonin · Older patients · Cancer · Quality of life · Chemotherapy

Angeline Ginzac

Angeline.Ginzac@clermont.unicancer.fr

1 Université Clermont Auvergne, INSERM, U1240 Imagerie Moléculaire et Stratégies Théranostiques, Centre Jean PERRIN, 63011 Clermont-Ferrand, France

2 Division de Recherche Clinique, Délégation Recherche Clinique et Innovation, Centre de Lutte contre le Cancer, Centre Jean PERRIN, 58, rue Montalembert, 63011 Clermont-Ferrand Cedex 1, France

3 Centre d'Investigation Clinique, UMR501, 63011 Clermont-Ferrand, France

4 Département d'Oncologie Médicale, Centre Jean PERRIN, 63011 Clermont-Ferrand, France

5 CHU Clermont-Ferrand, Gérontopole, 63003 Clermont-Ferrand, France

6 Département de Radiothérapie, Centre Jean PERRIN, 63011 Clermont-Ferrand, France

\section{Background}

In 2018, 18.1 million new cancers were recorded worldwide and 9.6 million deaths were attributed to cancer [1]. Europe accounts for $9 \%$ of the world's population, but for $23.4 \%$ of all cancer cases and for $20.3 \%$ of cancer deaths [1]. For most types of cancer, incidence rates increase with age. In the USA, an increase in cancer incidence from 2010 to 2030 of $67 \%$ has been estimated for people of 65 years or older, compared to an increase of only $11 \%$ among patients younger than 65 years [2]. The management of cancer among elderly patients is a public health problem.

The age of 70 is a threshold commonly used in clinical trials in oncology, but some authors use 65 as a reference age [3]. The European Medicines Agency (EMA) considers 65 years as a cut-off for the definition of old age (E7 Studies in Support of Special Populations: geriatrics). Despite the high frequency of cancer in the elderly population, these patients are under-represented in clinical trials 
[4-6]. Among studies by the National Cancer Institute on early stage breast cancer, only $18 \%$ of patients were over 65 years, while this population accounts for $49 \%$ of eligible patients [7]. Thus, we note here the importance of taking into account this population in clinical trials to improve current therapeutic treatment.Cancers among older patients are often diagnosed late and they often remain undertreated [8]. Late diagnoses can affect survival in this subpopulation [9]. The main reasons for the late diagnosis of cancer are comorbidities, the lack of a supportive social environment, difficulties in accessing public transport and deteriorating cognitive function [10]. A detailed study of the literature data has shown that compared to younger patients, older patients are subjected to a higher percentage of certain types of cancer at advanced stages [8], and also a higher percentage of non-staged cancers and a higher percentage of nonhistological or non-cytological confirmations of cancer [11]. In fact, the study by De Rijke et al., performed on a cohort of 6911 patients aged 50 or over showed that, overall, $16 \%$ of patients were not treated, with the percentage rising to $22 \%$ for those over 70 years of age [11].

Elderly patients present particular characteristics that make the choice of the appropriate treatment more difficult to determine. The elderly population is very heterogeneous and cancer treatment for these patients requires knowledge not only of the disease but also of the physiological and pathophysiological features associated with aging. In oncology, as all anti-cancer drugs have side effects, it is important to consider the benefits and the risks associated with these treatments, especially in the elderly population. They are indeed more vulnerable to treatment toxicities and are more likely to have side effects [12]. Indeed, age is associated with several physiological changes in organ function that could alter drug pharmacokinetics and have an impact on cytotoxic chemotherapy tolerability and toxicity [12]. For example, we can mention the decline in renal function [13], diminishing bone marrow reserves [14], anaemia [15], poor nutrition [16] or even changes within the gastrointestinal system [17]. Geriatric syndromes (e.g., impaired vision and hearing, incontinence, poor nutrition) engender additional considerable difficulties for the treatment of the elderly [18].

In addition, comorbidities have an impact on the choice of treatment (e.g., anthracyclin, increasing the risk of cardiotoxicity such as heart failure, cisplatin, increasing the risk of renal failure) and they could lead to poly-medication, which contributes to increased chemotherapy toxicity among older patients [12].

As described above, the older cancer population is heterogeneous and complex (comorbidities, general health, drug interactions, dosage adjustment) and maintaining quality of life (QoL) is a major challenge in the care of these patients $[19,20]$. In advanced disease, treatment is palliative, where the aim is to control the disease and pain, limit toxicities and maintain an overall level of QoL. However, with age, the pineal gland produces less melatonin. Melatonin regulates a wide variety of physiological functions and is involved in the initiation of sleep and the improvement of QoL. Thus melatonin has potential value in cancer pathologies in addition to the standard treatment to prevent and/or reduce the symptoms associated with cancer and its management, such as asthenia, depressive syndromes, sleep disorders, cognitive decline or even performance status, these dimensions being constitutive of QoL. The absence of any particular toxicity [21-23] in various clinical trials and the possible antitumor efficacy of melatonin strengthen its beneficial roles. Finally, the use of melatonin as a therapeutic strategy seems particularly suitable for older patients, a population known to secrete significantly less melatonin. However, to date no studies have been conducted in this population. This article aims to review the interest of melatonin for older patients with cancer to improve their quality of life during treatment.

\section{Methods}

A literature search was conducted on PubMed database. The search terms and derivatives of "metastatic cancer", "older patients", "quality of life" and "melatonin" were used. Titles and abstracts were screened to identify whether studies were relevant for full-text screening. Only English-language studies were included. Articles were selected for full-text screening if the title or abstract mentioned one or more search terms.

\section{Older patients with cancer and quality of life}

In 1993, the World Health Organization (WHO) defined QoL as "an individual's perception of their position in life in the context of the culture and the value systems in which they live and in relation to their goals, expectations, standards and concerns" [24]. Health-related QoL (HRQoL) is a multidimensional concept including the physical, mental and social fields and the symptoms related to the disease and treatment [25]. Several studies have highlighted the prognostic value of data from HRQoL measures for cancer patients, especially in the advanced stages [26-29].

Two measurement tools are primarily used in oncology: the Functional Assessment of Cancer Therapy (FACT) [30] and the European Organization for Research and Treatment of Cancer Quality of Life Questionnaire Core 30 (EORTC QLQ-C30) [31], appropriate for self-evaluation and applicable across a wide range of settings. The core questionnaire is supplemented by disease-specific modules, e.g. breast, lung, head and neck cancer, palliative care, and a specific module for the elderly (QLQ ELD14). 
There is major concern about the symptoms older cancer patients have to cope with during treatment because they can impact their QoL. Particularly at the metastatic stage, the aim of therapeutic management is to control the main symptoms. Thus QoL research incorporates these dimensions and is particularly relevant for decisional management for older patients with metastatic cancer. It is important to underline that the cancer treatment itself influences QoL (e.g., chemoinduced anaemia, asthenia, anorexia, reduced mobility, or even depressive symptoms) [32]. Pain, fatigue, insomnia and mood disturbance are the four most common symptoms and the most distressful that were reported by elderly patients with cancer during the illness and treatment [33]. The interrelations in this cluster of symptoms could affect QoL [34].

A study on 120 patients ( $>65$ years), receiving cancer therapy showed that the patients had numerous symptoms, with a mean number of $5 \pm 3$ symptoms per patient. Mood disturbance was the most prevalent (87\%). The high-symptom group obtained a significantly lower mean Karnofsky performance score and FACT-G sub-scale and total scores $(p<0.01)$ (Cheng and Yeung, 2013). A recent study on 74 older patients with solid tumours showed a significant increase in excessive daytime sleepiness (EDS) after chemotherapy [from 6 patients (8.1\%) exhibiting EDS at baseline to 16 patients $(21.6 \%)$ after chemotherapy; $p<0.01]$. The authors concluded that this impact of chemotherapy on daytime sleepiness could affect quality of life [35].

Furthermore, the management of cancer, and chemotherapy in particular, can induce a disruption of the circadian system, which can impact quality of life negatively. Mormont et al., in a study on 200 metastatic colorectal cancer patients, demonstrated a link between the rest-activity rhythm and QoL, showing a positive correlation between $24 \mathrm{~h}$ rhythm indicators and the global QLQ-C30 global score [36]. Innominato et al., in a study on 96 patients with metastatic colorectal cancer also showed that disruption of the circadian system was associated with lower QoL, global and in various domains, including the social environment [37]. The same team conducted another study on 237 metastatic colorectal cancer patients. They highlighted that fatigue and anorexia were more marked among patients with circadian disruption, and that QoL was better for patients with a robust circadian rhythm. The authors concluded that circadian disruption was associated with cancer symptoms and had an impact on physical and social functioning. Furthermore, they showed that the circadian system was important in the level of HRQoL for patients with cancer [38].

Several studies have shown a link between circadian rhythm disruption and survival among patients with cancer especially in metastatic colorectal cancer [39], advanced breast cancer [40], and lung cancer [41]. In the study by Innominato et al., circadian disruption among patients with metastatic colon cancer was a pejorative prognostic factor for overall survival, independently from other known prognostic factors [37]. The disruption of the circadian clock can also be caused by the chemotherapy itself. A study on 77 patients showed that chemotherapy-induced circadian disruption was also associated with significantly shorter survival [42]. Thus, these results justify the development of specific therapies aiming to restore the circadian system, which could potentially improve survival among cancer patients undergoing treatment.

\section{Interrelation between melatonin, older patients with cancer and quality of life}

Melatonin is a compound synthesized by the pineal gland in the human brain. It is considered as a hormone regulating the circadian day-night rhythm. Tryptophan and serotonin are the precursors of melatonin. The regulation of melatonin synthesis is controlled by the light-dark cycle, acting through neural activation of the anterior hypothalamus CNS, via the axons of the retinal ganglion cells running from the optic nerves and forming the retino-hypothalamic tract). The secretion of melatonin has a typical circadian rhythm, reaching a peak value $(80-150 \mathrm{pg} / \mathrm{ml})$ between midnight and 3 a.m. $[43,44]$.

Since its discovery, many in vitro studies and animal models have been developed to determine the specific roles of melatonin in the body: antioxidant and onco-static properties [45, 46]; an anti-angiogenic role [47]; control of the immune system [48]; its role in sleep (reduced sleep latency and induction of sleepiness and drowsiness) [49]; its role in disorders of the biological rhythms [50].

Melatonin is metabolized in the liver and excreted in the urine as 6-sulfatoxymelatonin [51]. Due to the rapid absorption and short half-life of melatonin (40-50 min) after intake of an exogenous sustained-release formulation, a maximum plasma concentration occurring between 20 and $240 \mathrm{~min}$ is observed, followed by a decline after less than one and a half hours, depending on the dose [52]. Maintaining effective body concentrations of melatonin throughout the night thus requires either a high dose or an exogenous sustained-release formulation.

For example, $\operatorname{Circadin}^{\odot}$ is an exogenous sustained-release formulation of melatonin, which overcomes the rapid clearance of the hormone in the intestine over an extended period of time, thus mimicking the physiological pattern of melatonin secretion. Thereby, the peak plasma concentration is reached $2.6 \mathrm{~h}$ after intake and lasts an additional three and a half hours before falling, covering the whole night-time duration. In 2007, Circadin ${ }^{\circledR}$ received its authorization on the European market as a monotherapy. It should be taken $2 \mathrm{~h}$ prior to bedtime and it can be used in the short-term treatment of primary insomnia among adults aged 55 and over. This authorization is based on results from two studies 
on patients ( $>55$ years) with primary insomnia [53, 54]. These studies and a meta-analysis [55] showed a significant benefit on sleep latency. This benefit is similar to that obtained from the already marketed hypnotics (sleep latency shortened by $25 \mathrm{~min}$ on average). In addition, these studies showed significant benefits in sleep quality, morning alertness and patient QoL. The aforementioned studies also showed that tolerance of the treatment is comparable to that of a placebo. After stopping the treatment for three nights, sleep quality deteriorates, but is still better among patients taking Circadin ${ }^{\circledR}$, suggesting that there are not only no withdrawal symptoms and no risk in stopping treatment, but also that the treatment has a residual beneficial effect.

In these clinical trials, the most common side effects reported were headache, nasopharyngitis, back pain and arthralgia; they were observed in both the $\operatorname{Circadin}^{\odot}$ and the placebo groups.

With its role in the control of the circadian rhythm, we can hypothesize that, an intake of melatonin could have a beneficial effect on QoL and systemic symptoms. It can be remarked that, in humans, the pineal gland becomes less functional with age and melatonin levels gradually decline through life [56]. The causes of the decrease in melatonin secretion are not fully understood at this stage, and several hypotheses have been suggested, such as CNS degeneration, calcification of the pineal gland, or abnormal transmission of light signals [57]. Another hypothesis suggested is a decrease in melatonin receptors (MT1) in the brain, which is age related [58].

Between 40 and $70 \%$ of people suffer from sleep disorders, potentially affecting their psychological, social and cognitive functioning, and thus affecting their QoL [59]. Melatonin secretion is inversely correlated with sleep disturbances during the aging process. One study also demonstrated a link between reductions in urinary melatonin and poor quality of sleep in the elderly, and delayed sleep phase, identified by comparison with a control group of the same age [49].

\section{Benefits of melatonin supplementation for older cancer patients}

Table 1 summarizes the main findings described in this section.

\section{Combined effects of melatonin with chemotherapy: improving survival}

The effect of melatonin coupled with chemotherapy has been analysed in different cancers. Several trials support the hypothesis that melatonin enhances the effect of chemotherapy, especially in colorectal carcinoma Cerea et al. evaluated the effect of simultaneous administration of melatonin and camptothecin (Irinotecan ${ }^{\odot}$ ) to 30 patients with metastatic colorectal carcinoma. They showed that melatonin with Irinotecan ${ }^{\odot}$ was more effective in controlling the disease than Irinotecan ${ }^{\odot}$ alone [60].

A recent meta-analysis [23] of eight clinical trials tested the effect of melatonin supplementation among 761 patients treated with chemotherapy or radiation therapy for solid tumors in metastatic setting. The tested melatonin dose was $20 \mathrm{mg} /$ day, prescribed concurrently with chemotherapy and/ or radiotherapy. Melatonin significantly improved complete and partial remission rates ( 16.5 vs. $32.6 \%$; risk ratio $\mathrm{RR}=1.95,95 \% \mathrm{CI} 1.49-2.54 ; p<0.00001)$ as well as 1 -year survival (28.4 vs. $52.2 \%$; RR $=1.90 ; 95 \%$ CI $1.28-2.83$; $p=0.001)$. However, it is important to remain cautious because this meta-analysis included six studies conducted in the same centre on a small study population. Hence, an analysis using double-blind placebo and multicentre studies with larger patient samples is needed to evaluate the efficacy of melatonin in the treatment of cancer.

Another meta-analysis [22] included a larger group of trials (21 trials). The trials combined adjuvant chemotherapy with melatonin. Melatonin decreased 1-year mortality $(\mathrm{RR}=0.60,95 \% \mathrm{CI} 0.54-0.67)$ and contributed to improved results for complete response, partial response and stable disease, with RR of 2.53 (1.36-4.71), 1.70 (1.37-2:12), and 1.15 (1.00-1.33), respectively.

\section{Improvement of symptoms induced by cancer and its treatment}

A study [21] on 200 patients with chemotherapy-resistant metastatic cancer, comparing chemotherapy versus chemotherapy + melatonin at a dose of $20 \mathrm{mg} /$ day for at least 2 months, showed a significant reduction in chemotherapyinduced toxicities such as asthenia, thrombocytopenia, neurotoxicity and stomatitis. Another study conducted by the same team [21] showed a significant reduction in certain cancer-induced symptoms by providing melatonin to 1440 patients: 718 patients treated with supportive care alone, and 722 treated with supportive care + melatonin at $20 \mathrm{mg} /$ day. The symptoms that improved were cachexia, asthenia, anorexia, depressive syndromes and thrombocytopenia.

A recent study conducted on 32 metastatic breast cancer patients who took $5 \mathrm{mg} /$ day of melatonin for two months at bedtime showed a reduction in sleep fragmentation $(p=0,0015)$ and an increase in sleep duration [61]. Similarly, a double-blind, placebo-controlled, randomized study among breast cancer patients comparing $6 \mathrm{mg} /$ day of melatonin $(n=27)$ to placebo $(n=21)$, from three nights before surgery until one week post-surgery, showed an increase in sleep efficacy in the melatonin group $(p=0,007)$ and a reduction in waking-after-sleep onset [62]. Also according to the above-mentioned meta-analysis [22, 23], melatonin 
Table 1 Benefits of melatonin supplementation for cancer patients

\begin{tabular}{|c|c|c|c|c|c|c|}
\hline $\begin{array}{l}\text { Refer- } \\
\text { ences }\end{array}$ & $\begin{array}{l}\mathrm{Nb} \text { of } \\
\text { patients }\end{array}$ & Endpoints & Design & Dosage MLT & Outcome & $\begin{array}{l}\text { Level of } \\
\text { evidence }\end{array}$ \\
\hline $\begin{array}{l}\text { Innomi- } \\
\text { nato } \\
\text { [37] }\end{array}$ & 32 & $\begin{array}{l}\text { To assess the effect } \\
\text { of MLT on circa- } \\
\text { dian biomarkers, } \\
\text { sleep, and quality } \\
\text { of life in meta- } \\
\text { static breast cancer } \\
\text { patients }\end{array}$ & $\begin{array}{l}\text { Prospective open } \\
\text { label, phase II trial }\end{array}$ & $\begin{array}{l}5 \mathrm{mg} / \text { day taken orally } \\
\text { at each patient's } \\
\text { usual bedtime for } \\
2 \text { months }\end{array}$ & $\begin{array}{l}\text { Daily bedtime MLT therapy is } \\
\text { associated with reduction in sleep } \\
\text { fragmentation, increases in sleep } \\
\text { duration, improvements in self- } \\
\text { rated sleep quality and improve- } \\
\text { ment in global QoL and pertinent } \\
\text { social and cognitive domains, } \\
\text { as well as reduction in fatigue } \\
\text { severity. Without any short-term } \\
\text { toxicity }\end{array}$ & $1 \mathrm{c}$ \\
\hline \multirow[t]{2}{*}{$\begin{array}{c}\text { Lissoni } \\
\text { [64] }\end{array}$} & 1140 & $\begin{array}{l}\text { Efficacy of MLT } \\
\text { in patients with } \\
\text { untreatable } \\
\text { advanced solid } \\
\text { tumors who had } \\
\text { responded to previ- } \\
\text { ous standard anti- } \\
\text { cancer therapies } \\
\text { and for whom no } \\
\text { other effective con- } \\
\text { ventional treatment } \\
\text { was available }\end{array}$ & $\begin{array}{l}\text { Randomization } \\
\text { according to tumor } \\
\text { type: supportive } \\
\text { care alone or sup- } \\
\text { portive care + MLT }\end{array}$ & $\begin{array}{l}20 \mathrm{mg} / \text { day during the } \\
\text { dark period }\end{array}$ & $\begin{array}{l}\text { MLT may be effective in the } \\
\text { prevention of both cancer } \\
\text { progression-related symptoms } \\
\text { and chemotherapy-induced toxic- } \\
\text { ity: role in the supportive care of } \\
\text { cancer patients } \\
\text { MLT may have potential antican- } \\
\text { cer activity whether given alone } \\
\text { or in association with cancer } \\
\text { chemotherapy. The } 1 \text {-year sur- } \\
\text { vival curve achieved in patients } \\
\text { concomitantly treated with MLT }\end{array}$ & $1 \mathrm{~b}$ \\
\hline & 200 & $\begin{array}{l}\text { efficacy of con- } \\
\text { comitant MLT } \\
\text { administration on } \\
\text { chemotherapy- } \\
\text { induced toxicity } \\
\text { and therapeutic } \\
\text { activity in previ- } \\
\text { ously untreated } \\
\text { patients with } \\
\text { metastatic solid } \\
\text { tumours who had } \\
\text { chemo-resistant } \\
\text { cancer and a good } \\
\text { clinical status }\end{array}$ & $\begin{array}{l}\text { Randomization } \\
\text { according to the } \\
\text { chemotherapeutic } \\
\text { regimen: chemo- } \\
\text { therapy alone } \\
\text { or chemother- } \\
\text { apy + MLT }\end{array}$ & $\begin{array}{l}20 \mathrm{mg} / \text { day during the } \\
\text { dark period }\end{array}$ & $\begin{array}{l}\text { was significantly higher than that } \\
\text { for patients who received chemo- } \\
\text { therapy alone }(P<0.05)\end{array}$ & \\
\hline Cerea [60] & 30 & $\begin{array}{l}\text { To evaluate the influ- } \\
\text { ence of a concomi- } \\
\text { tant administration } \\
\text { of MLT on CPT-11 } \\
\text { therapeutic activ- } \\
\text { ity in metastatic } \\
\text { colorectal cancer } \\
\text { patients progress- } \\
\text { ing after at least } \\
\text { one previous } \\
\text { chemotherapeutic } \\
\text { line containing } \\
5 \text { FU }\end{array}$ & $\begin{array}{l}\text { Randomization: } \\
\text { treatment with } \\
\text { CPT11 alone or } \\
\text { CPT11 + MLT } \\
\text { (CPT11: I.V. } 125 \mathrm{mg} / \\
\text { m²/week for } 9 \text { con- } \\
\text { secutive week) }\end{array}$ & $\begin{array}{l}\text { orally } 20 \mathrm{mg} / \text { day dur- } \\
\text { ing the dark period } \\
\text { of the day }\end{array}$ & $\begin{array}{l}\text { This preliminary study shows } \\
\text { that the efficacy of weekly low- } \\
\text { dose CPT-11 in pretreated meta- } \\
\text { static colorectal can- } \\
\text { cer patients may be enhanced by a } \\
\text { concomitant daily administration } \\
\text { of the pineal hormone MLT, } \\
\text { according to the results previously } \\
\text { reported for other chemotherapeu- } \\
\text { tic agents }\end{array}$ & $1 b$ \\
\hline
\end{tabular}


Table 1 (continued)

\begin{tabular}{|c|c|c|c|c|c|c|}
\hline $\begin{array}{l}\text { Refer- } \\
\text { ences }\end{array}$ & $\begin{array}{l}\mathrm{Nb} \text { of } \\
\text { patients }\end{array}$ & Endpoints & Design & Dosage MLT & Outcome & $\begin{array}{l}\text { Level of } \\
\text { evidence }\end{array}$ \\
\hline $\begin{array}{c}\text { Lissoni } \\
\text { [64] }\end{array}$ & 40 & $\begin{array}{l}\text { MLT could amplify } \\
\text { the efficacy of } \\
\text { TMX in post-men- } \\
\text { opausal metastatic } \\
\text { breast cancer } \\
\text { patients } \\
\text { with negative ER, }\end{array}$ & $\begin{array}{l}\text { Randomized study } \\
\text { TMX (tamoxifen) } \\
\text { versus TMX + MLT }\end{array}$ & $\begin{array}{l}20 \mathrm{mg} / \text { day orally in } \\
\text { the evening }\end{array}$ & $\begin{array}{l}\text { No complete response was seen. } \\
\text { Partial response rate was signifi- } \\
\text { cantly higher in patients treated } \\
\text { with TMX plus MLT than in } \\
\text { those who received TMX alone } \\
\text { The percent of survival at } 1 \text { year } \\
\text { was significantly higher in } \\
\text { patients treated with TMX + MLT } \\
\text { than in those treated with TMX } \\
\text { alone } \\
\text { The association of the pineal } \\
\text { hormone MLT may make TMX } \\
\text { effective in ER-negative meta- } \\
\text { static breast cancer patients }\end{array}$ & $1 b$ \\
\hline $\begin{array}{c}\text { Madsen } \\
\text { [63] }\end{array}$ & 48 & $\begin{array}{l}\text { To investigate } \\
\text { whether adminis- } \\
\text { tration of an oral } \\
\text { dose of } 6 \mathrm{mg} \text { MLT } \\
\text { before bedtime } \\
\text { perioperatively in } \\
\text { breast cancer sur- } \\
\text { gery could change } \\
\text { sleep outcomes } \\
\text { measured by actig- } \\
\text { raphy }\end{array}$ & $\begin{array}{l}\text { Double blind, } \\
\text { placebo-controlled, } \\
\text { randomized clinical } \\
\text { trial } \\
27 \text { patients received } \\
6 \mathrm{mg} \text { MLT } \\
21 \text { patients received } \\
\text { placebo }\end{array}$ & $\begin{array}{l}6 \text { mg/day approxi- } \\
\text { mately } 60 \text { min } \\
\text { before bedtime } 3 \\
\text { nights preopera- } \\
\text { tively until at least } \\
1 \text { week postopera- } \\
\text { tively }\end{array}$ & $\begin{array}{l}\text { Administration of } 6 \text { mg oral MLT } \\
\text { significantly increased sleep effi- } \\
\text { ciency and reduced waked after } \\
\text { sleep onset for the entire } 2 \text {-week } \\
\text { postoperative period } \\
\text { But MLT had no effects on other } \\
\text { objective sleep outcomes or on } \\
\text { subjective sleep quality }\end{array}$ & $1 \mathrm{~b}$ \\
\hline $\begin{array}{c}\text { Hansen } \\
{[65]}\end{array}$ & 54 & $\begin{array}{l}\text { Investigate whether } \\
\text { MLT could lower } \\
\text { the risk of depres- } \\
\text { sive symptoms } \\
\text { in women with } \\
\text { breast cancer in a } \\
\text { three-month period } \\
\text { after surgery and } \\
\text { assessed the effect } \\
\text { of melatonin on } \\
\text { subjective parame- } \\
\text { ters (anxiety, sleep, } \\
\text { general well-being, } \\
\text { fatigue, pain and } \\
\text { sleepiness) }\end{array}$ & $\begin{array}{l}\text { Randomized, double- } \\
\text { blind, placebo- } \\
\text { controlled trial } \\
28 \text { patients received } \\
\text { MLT } \\
26 \text { patients received } \\
\text { placebo }\end{array}$ & $\begin{array}{l}6 \mathrm{mg} / \text { day } 1 \mathrm{~h} \text { before } \\
\text { bedtime for } 1 \text { week } \\
\text { preoperatively and } \\
12 \text { weeks ostopera- } \\
\text { tively }\end{array}$ & $\begin{array}{l}\text { MLT significantly reduced the } \\
\text { risk of depressive symptoms in } \\
\text { women with breast cancer during } \\
\text { a three-month period after surgery }\end{array}$ & $1 \mathrm{~b}$ \\
\hline $\begin{array}{l}\text { Del Fab- } \\
\text { bro [67] }\end{array}$ & 48 & $\begin{array}{l}\text { To compare MLT } \\
\text { with placebo for } \\
\text { appetite improve- } \\
\text { ment in patients } \\
\text { with cancer } \\
\text { cachexia (patients } \\
\text { with advanced lung } \\
\text { or GI) }\end{array}$ & $\begin{array}{l}\text { Randomized, double- } \\
\text { blind, 28-day trial } \\
\text { of MLT } 20 \mathrm{mg} \\
\text { at night versus } \\
\text { placebo }\end{array}$ & $\begin{array}{l}20 \mathrm{mg} / \text { day at night } \\
\text { during } 28 \text { days }\end{array}$ & $\begin{array}{l}\text { No significant difference between } \\
\text { groups for appetite or other } \\
\text { symptoms, weight, FAACT score, } \\
\text { toxicity, or survival baseline to } \\
\text { day } 28 \\
\text { In cachectic patients with advanced } \\
\text { cancer, oral MLT } 20 \mathrm{mg} \text { at night } \\
\text { did not improve appetite, weight, } \\
\text { or quality of life compared with } \\
\text { placebo } \\
\text { The trial was stopped after interim } \\
\text { analysis }\end{array}$ & $1 \mathrm{~b}$ \\
\hline
\end{tabular}


Table 1 (continued)

\begin{tabular}{|c|c|c|c|c|c|c|}
\hline $\begin{array}{l}\text { Refer- } \\
\text { ences }\end{array}$ & $\begin{array}{l}\mathrm{Nb} \text { of } \\
\text { patients }\end{array}$ & Endpoints & Design & Dosage MLT & Outcome & $\begin{array}{l}\text { Level of } \\
\text { evidence }\end{array}$ \\
\hline $\begin{array}{l}\text { Sookpra- } \\
\text { sert [68] }\end{array}$ & $\begin{array}{l}151 \text { patients } \\
\text { with his- } \\
\text { tologically } \\
\text { advanced } \\
\text { NSCLC }\end{array}$ & $\begin{array}{l}\text { Health-related QoL } \\
\text { assessed with the } \\
\text { Functional Assess- } \\
\text { ment of Cancer } \\
\text { Therapy_Lung }\end{array}$ & $\begin{array}{l}\text { Randomized, double- } \\
\text { blind, placebo- } \\
\text { controlled trial } \\
\text { A: } 10 \mathrm{mg} \text { MLT } \\
\text { B: } 20 \mathrm{mg} \text { MLT } \\
\text { C: Placebo }\end{array}$ & $\begin{array}{l}\text { after } 21 \mathrm{~h} \text { on the first } \\
\text { day of chemo- } \\
\text { therapy treatment } \\
\text { and continue for } \\
6 \text { months }\end{array}$ & $\begin{array}{l}\text { When used in combination with } \\
\text { chemotherapy, MLT did not } \\
\text { significantly affect survival and } \\
\text { adverse events of patients with } \\
\text { advanced NSCLC, but there was } \\
\text { a trend for better HRQoL in the } \\
\text { melatonin-treated groups, with a } \\
\text { significantly better score in social } \\
\text { well-being }\end{array}$ & $1 b$ \\
\hline Wang [23] & 761 & $\begin{array}{l}\text { To observe MLT } \\
\text { effect on tumor } \\
\text { remission, 1-year } \\
\text { survival and side } \\
\text { effects due to } \\
\text { radiochemotherapy }\end{array}$ & $\begin{array}{l}\text { Meta-analyses of } \\
\text { eight randomized } \\
\text { clinical trials } \\
\text { (patients with solid } \\
\text { tumor cancers) }\end{array}$ & $\begin{array}{l}20 \mathrm{mg} \text { orally, once } \\
\text { a day }\end{array}$ & $\begin{array}{l}\text { MLT significantly improved: } \\
\text { the complete and partial remission } \\
(16.5 \text { vs. } 32.6 \% ; \mathrm{RR}=1.95,95 \% \\
\text { CI } 1.49-2.54 ; p<0.00001) \\
\text { 1-year survival rate }(28.4 \text { vs. } 52.2 \% \text {; } \\
\text { RR }=1.90 ; 95 \% \text { CI } 1.28-2.83 ; \\
p=0.001) \\
\text { decreased radiochemotherapy- } \\
\text { related side effects including } \\
\text { thrombocytopenia }(19.7 \text { vs. } 2.2 \% \text {; } \\
\text { RR }=0.13 ; 95 \% \text { CI, } 0.06-0.28 ; \\
p<0.00001), \text { neurotoxicity }(15.2 \\
\text { vs. } 2.5 \% ; \mathrm{RR}=0.19 ; 95 \% \text { CI, } \\
0.09-0.40 ; p<0.0001) \text { and fatigue } \\
(49.1 \text { vs. } 17.2 \% ; \mathrm{RR}=0.37 ; 95 \% \\
\text { CI } 0.28-0.48 ; p<0.00001)\end{array}$ & $1 \mathrm{a}$ \\
\hline Seely [22] & UK & $\begin{array}{l}\text { 1-year mortality, } \\
\text { complete response, } \\
\text { partial response, } \\
\text { stable disease }\end{array}$ & $\begin{array}{l}\text { Meta-analyses of } 21 \\
\text { clinical trials (solid } \\
\text { tumors) }\end{array}$ & UK & $\begin{array}{l}\text { MLT may benefit cancer patients } \\
\text { who are also receiving chemo- } \\
\text { therapy, radiotherapy, supportive } \\
\text { therapy, or palliative therapy by } \\
\text { improving survival and ameliorat- } \\
\text { ing the side effects of chemo- } \\
\text { therapy }\end{array}$ & $1 \mathrm{a}$ \\
\hline
\end{tabular}

1a: systematic review or meta-analysis of randomized controlled trials (RCT) of good methodological quality and with homogeneity; 1b: individual RCT with narrow CI; 1c: non-controlled studies

$M L T$ melatonin, $U K$ unknown

significantly reduces symptoms such as asthenia, leukopenia, nausea and vomiting, hypotension, and thrombocytopenia. As most of these symptoms are included in QoL measures, their improvement by melatonin could translate into patient QoL improvement.

\section{Role on quality of life}

In a randomized study [63], an improvement of anxiety and depressive symptoms was observed among patients treated for metastatic breast cancer with Tamoxifen ${ }^{\odot}+$ melatonin. Another more recent study [64] showed a significantly lower risk of developing depressive syndrome after surgery for breast cancer among 54 patients receiving melatonin supplementation ( $6 \mathrm{mg} /$ day, 3 months) versus placebo, RR 0.25 [95\% CI 0.077-0.80].

An improvement of performance status (PS) was observed among patients with non-small cell lung cancer resistant to first-line chemotherapy with cisplatin, treated with supportive care + melatonin at $10 \mathrm{mg}$ /day compared to patients treated with supportive care alone [65]. In addition, it is important to highlight that in many studies PS was correlated with QoL.

A double-blind trial [66] recently studied the effect of melatonin supplementation at $20 \mathrm{mg} /$ day for 4 weeks on appetite in cachexia patients with advanced cancer. At the interim analysis of 48 patients, the trial was stopped early for futility, noting the absence of any advantage for the melatonin arm. In this study, QoL was also assessed, but no apparent difference between the two groups was observed. However, it is difficult to take these results into account, because the study was not designed to conclude on QoL, which was a secondary objective.

Only one double-blind trial [67], recently studied the effect of melatonin supplementation (10 or $20 \mathrm{mg} /$ day) on QoL and reported a better meanadjusted QoL score 
(FACT-L) with a slightly significant better score (2.69 points, CI 0.01-5.38, $p=0.049$ ) found for social wellbeing.

However, melatonin supplementation for older patients could entail a weakness. Indeed, this subpopulation, because of their numerous comorbidities, often has a lot of tablets to take; this would add yet one more tablet, which could be a limitation. It is also important to emphasize that sustainedrelease formulation of melatonin is not reimbursed by social security system in France (except for children with specific syndromes). So another weakness is the price of the supplementation: approximately $30 €$ for 30 tablets of Circadin ${ }^{\circledR}$ $2 \mathrm{mg}$. Furthermore, in the studies, the dosage of melatonin varies from $5 \mathrm{mg} /$ day to $20 \mathrm{mg} /$ day while standard dosage of sustained-release formulation is $2 \mathrm{mg} /$ day (Table 1). The smaller dosages lead to good results with an improvement in quality of sleep and depressive symptoms [61, 62, 64]. A systematic review, conducted on 16 articles, concluded that optimal dosage for melatonin supplementation in older adults is the lowest possible dose because it is closest to physiological circadian rhythm of melatonin [68].

\section{Conclusion}

The use of melatonin as a therapeutic strategy seems particularly suitable for elderly patients, a population known to secrete significantly less melatonin. However, to date no studies have been conducted in this population. The elderly population is heterogeneous and complex (comorbidities, general health, drug interactions, dosage adjustment), and maintaining QoL is a major challenge in the care of elderly patients. In advanced disease, treatment is palliative and the aim is to control the disease and pain, limit toxicities and maintain an overall level of QoL. Thus, it seems appropriate to study the impact of melatonin supplementation during cytotoxic therapy on QoL among elderly metastatic cancer patients.

Author contributions SD, ET and XD has the idea for article; AG and SD performed the literature search, SD, ET, XD, AG drafted the work, $\mathrm{MOH}, \mathrm{FK}, \mathrm{JP}, \mathrm{JB}, \mathrm{CA}$, MAMR critically revised the work.

\section{Funding None.}

\section{Compliance with ethical standards}

Conflict of interest The authors declare that they have no conflict of interest.

Ethical approval Not applicable.

Informed consent Not applicable.
Open Access This article is licensed under a Creative Commons Attribution 4.0 International License, which permits use, sharing, adaptation, distribution and reproduction in any medium or format, as long as you give appropriate credit to the original author(s) and the source, provide a link to the Creative Commons licence, and indicate if changes were made. The images or other third party material in this article are included in the article's Creative Commons licence, unless indicated otherwise in a credit line to the material. If material is not included in the article's Creative Commons licence and your intended use is not permitted by statutory regulation or exceeds the permitted use, you will need to obtain permission directly from the copyright holder. To view a copy of this licence, visit http://creativecommons.org/licenses/by/4.0/.

\section{References}

1. Bray F, Ferlay J, Soerjomataram I et al (2018) Global cancer statistics 2018: GLOBOCAN estimates of incidence and mortality worldwide for 36 cancers in 185 countries. CA Cancer J Clin 68:394-424. https://doi.org/10.3322/caac.21492

2. Smith BD, Smith GL, Hurria A et al (2009) Future of cancer incidence in the United States: burdens upon an aging, changing nation. J Clin Oncol 27:2758-2765. https://doi.org/10.1200/ JCO.2008.20.8983

3. Balducci L (2000) Geriatric oncology: challenges for the new century. Eur J Cancer 36:1741-1754. https://doi.org/10.1016/s0959 -8049(00)00169-6

4. Downing NS, Shah ND, Neiman JH et al (2016) Participation of the elderly, women, and minorities in pivotal trials supporting 2011-2013 US. Food and drug administration approvals. Trials 17:199. https://doi.org/10.1186/s13063-016-1322-4

5. Hurria A, Dale W, Mooney M et al (2014) Designing therapeutic clinical trials for older and frail adults with cancer: U13 conference recommendations. J Clin Oncol 32:2587-2594. https://doi. org/10.1200/JCO.2013.55.0418

6. Hutchins LF, Unger JM, Crowley JJ et al (1999) Underrepresentation of patients 65 years of age or older in cancer-treatment trials. N Engl J Med 341:2061-2067. https://doi.org/10.1056/NEJM1 99912303412706

7. Lewis JH, Kilgore ML, Goldman DP et al (2003) Participation of patients 65 years of age or older in cancer clinical trials. J Clin Oncol 21:1383-1389. https://doi.org/10.1200/JCO.2003.08.010

8. Freyer G, Braud A-C, Chaibi P et al (2006) Dealing with metastatic breast cancer in elderly women: results from a French study on a large cohort carried out by the "Observatory on Elderly Patients”. Ann Oncol 17:211-216. https://doi.org/10.1093/annon c/mdj043

9. Bouchardy C, Rapiti E, Fioretta G et al (2003) Undertreatment strongly decreases prognosis of breast cancer in elderly women. J Clin Oncol 21:3580-3587. https://doi.org/10.1200/ JCO.2003.02.046

10. Goodwin JS, Hunt WC, Samet JM (1993) Determinants of cancer therapy in elderly patients. Cancer 72:594-601

11. de Rijke JM, Schouten LJ, Schouten HC et al (1996) Age-specific differences in the diagnostics and treatment of cancer patients aged 50 years and older in the province of Limburg The Netherlands. Ann Oncol 7:677-685

12. Popa MA, Wallace KJ, Brunello A et al (2014) Potential drug interactions and chemotoxicity in older patients with cancer receiving chemotherapy. J Geriatr Oncol 5:307-314. https://doi. org/10.1016/j.jgo.2014.04.002

13. Lichtman SM, Wildiers H, Launay-Vacher V et al (1990) (2007) International society of geriatric oncology (SIOG) recommendations for the adjustment of dosing in elderly cancer patients with 
renal insufficiency. Eur J Cancer Oxf Engl 43:14-34. https://doi. org/10.1016/j.ejca.2006.11.004

14. Dees EC, O'Reilly S, Goodman SN et al (2000) A prospective pharmacologic evaluation of age-related toxicity of adjuvant chemotherapy in women with breast cancer. Cancer Invest 18:521-529

15. Wu WC, Rathore SS, Wang Y et al (2001) Blood transfusion in elderly patients with acute myocardial infarction. N Engl J Med 345:1230-1236. https://doi.org/10.1056/NEJMoa010615

16. Landi F, Zuccalà G, Gambassi G et al (1999) Body mass index and mortality among older people living in the community. J Am Geriatr Soc 47:1072-1076

17. Baker SD, Grochow LB (1997) Pharmacology of cancer chemotherapy in the older person. Clin Geriatr Med 13:169-183

18. Kane RL, Ouslander JG, Abrase IB (1989) The is of geriatric syndromes. Essent Clin Geriatr Ed 2

19. Lavdaniti M, Zyga S, Vlachou E, Sapountzi-Krepia D (2017) Quality of life in elderly cancer patients undergoing chemotherapy. Adv Exp Med Biol 989:291-295. https://doi.org/10.1007/978-3319-57348-9_27

20. Naeim A, Aapro M, Subbarao R, Balducci L (2014) Supportive care considerations for older adults with cancer. J Clin Oncol 32:2627-2634. https://doi.org/10.1200/JCO.2014.55.3065

21. Lissoni $\mathrm{P}$ (2002) Is there a role for melatonin in supportive care? Support Care Cancer 10:110-116. https://doi.org/10.1007/s0052 00100281

22. Seely D, Wu P, Fritz $\mathrm{H}$ et al (2012) Melatonin as adjuvant cancer care with and without chemotherapy: a systematic review and meta-analysis of randomized trials. Integr Cancer Ther 11:293303. https://doi.org/10.1177/1534735411425484

23. Wang Y, Jin B, Ai F et al (2012) The efficacy and safety of melatonin in concurrent chemotherapy or radiotherapy for solid tumors: a meta-analysis of randomized controlled trials. Cancer Chemother Pharmacol 69:1213-1220. https://doi.org/10.1007/ s00280-012-1828-8

24. WHO (1995) The WORLD HEALTH ORGANIZATION QUALITY OF LIFE assessment (WHOQOL): position paper from the World Health Organization. Soc Sci Med 1982(41):1403-1409. https://doi.org/10.1016/0277-9536(95)00112-k

25. Cella DF (1994) Quality of life: concepts and definition. J Pain Symptom Manage 9:186-192

26. Ediebah DE, Quinten C, Coens C et al (2018) Quality of life as a prognostic indicator of survival: a pooled analysis of individual patient data from Canadian cancer trials group clinical trials. Cancer 124:3409-3416. https://doi.org/10.1002/cncr.31556

27. Kypriotakis G, Vidrine DJ, Francis LE, Rose JH (2016) The longitudinal relationship between quality of life and survival in advanced stage cancer. Psychooncology 25:225-231. https://doi. org/10.1002/pon.3846

28. Park S, Eo W, Lee S (2018) The relationship between healthrelated quality of life and survival in metastatic colorectal cancer patients treated with Korean medicine. Integr Cancer Ther 17:65-72. https://doi.org/10.1177/1534735416684015

29. Quinten C, Martinelli F, Coens C et al (2014) A global analysis of multitrial data investigating quality of life and symptoms as prognostic factors for survival in different tumor sites. Cancer 120:302-311. https://doi.org/10.1002/cncr.28382

30. Cella DF, Tulsky DS, Gray G et al (1993) The functional assessment of cancer therapy scale: development and validation of the general measure. J Clin Oncol 11:570-579

31. Aaronson NK, Ahmedzai S, Bergman B et al (1993) The European organization for research and treatment of cancer QLQ-C30: a quality-of-life instrument for use in international clinical trials in oncology. J Natl Cancer Inst 85:365-376

32. Kirkhus L, Harneshaug M, Šaltytė Benth J et al (2019) Modifiable factors affecting older patients' quality of life and physical function during cancer treatment. J Geriatr Oncol 10:904-912. https://doi.org/10.1016/j.jgo.2019.08.001

33. Van Lancker A, Velghe A, Van Hecke A et al (2014) Prevalence of symptoms in older cancer patients receiving palliative care: a systematic review and meta-analysis. J Pain Symptom Manage 47:90-104. https://doi.org/10.1016/j.jpainsymman.2013.02.016

34. Cheng KKF, Lee DTF (2011) Effects of pain, fatigue, insomnia, and mood disturbance on functional status and quality of life of elderly patients with cancer. Crit Rev Oncol Hematol 78:127-137. https://doi.org/10.1016/j.critrevonc.2010.03.002

35. Saberzadeh-Ardestani B, Khosravi B, Zebardast J, Sadighi S (2019) Chemotherapy effect on daytime sleepiness and contributing factors in older adults with cancer. J Geriatr Oncol 10:632636. https://doi.org/10.1016/j.jgo.2018.10.003

36. Mormont M-C, Waterhouse J (2002) Contribution of the restactivity circadian rhythm to quality of life in cancer patients. Chronobiol Int 19:313-323. https://doi.org/10.1081/cbi-12000 2606

37. Innominato PF, Focan C, Gorlia T et al (2009) Circadian rhythm in rest and activity: a biological correlate of quality of life and a predictor of survival in patients with metastatic colorectal cancer. Cancer Res 69:4700-4707. https://doi.org/10.1158/0008-5472. CAN-08-4747

38. Innominato PF, Komarzynski S, Palesh OG et al (2018) Circadian rest-activity rhythm as an objective biomarker of patient-reported outcomes in patients with advanced cancer. Cancer Med 7:43964405. https://doi.org/10.1002/cam4.1711

39. Mormont MC, Waterhouse J, Bleuzen P et al (2000) Marked 24-h rest/activity rhythms are associated with better quality of life, better response, and longer survival in patients with metastatic colorectal cancer and good performance status. Clin Cancer Res 6:3038-3045

40. Sephton SE, Sapolsky RM, Kraemer HC, Spiegel D (2000) Diurnal cortisol rhythm as a predictor of breast cancer survival. J Natl Cancer Inst 92:994-1000. https://doi.org/10.1093/jnci/92.12.994

41. Sephton SE, Lush E, Dedert EA et al (2013) Diurnal cortisol rhythm as a predictor of lung cancer survival. Brain Behav Immun 30(Suppl):S163-170. https://doi.org/10.1016/j.bbi.2012.07.019

42. Innominato PF, Giacchetti S, Bjarnason GA et al (2012) Prediction of overall survival through circadian rest-activity monitoring during chemotherapy for metastatic colorectal cancer. Int J Cancer 131:2684-2692. https://doi.org/10.1002/ijc.27574

43. Arendt J, Skene DJ (2005) Melatonin as a chronobiotic. Sleep Med Rev 9:25-39. https://doi.org/10.1016/j.smrv.2004.05.002

44. Claustrat B, Leston J (2015) Melatonin: physiological effects in humans. Neurochirurgie 61:77-84. https://doi.org/10.1016/j.neuch i.2015.03.002

45. Bonnefont-Rousselot D, Collin F (2010) Melatonin: action as antioxidant and potential applications in human disease and aging. Toxicology 278:55-67. https://doi.org/10.1016/j.tox.2010.04.008

46. Mediavilla MD, Sanchez-Barcelo EJ, Tan DX et al (2010) Basic mechanisms involved in the anti-cancer effects of melatonin. Curr Med Chem 17:4462-4481

47. Jardim-Perassi BV, Arbab AS, Ferreira LC et al (2014) Effect of melatonin on tumor growth and angiogenesis in xenograft model of breast cancer. PLoS ONE 9:e85311. https://doi.org/10.1371/ journal.pone.0085311

48. Carrillo-Vico A, Lardone PJ, Alvarez-Sanchez N et al (2013) Melatonin: buffering the immune system. Int J Mol Sci 14:8638-8683. https://doi.org/10.3390/ijms14048638

49. Haimov I, Laudon M, Zisapel N et al (1994) Sleep disorders and melatonin rhythms in elderly people. BMJ 309:167

50. Arendt J (1999) Jet-lag and shift work: (2). Therapeutic use of melatonin. J R Soc Med 92:402-405

51. Arendt J, Bojkowski C, Franey C et al (1985) Immunoassay of 6-hydroxymelatonin sulfate in human plasma and urine: abolition 
of the urinary 24-hour rhythm with atenolol. J Clin Endocrinol Metab 60:1166-1173. https://doi.org/10.1210/jcem-60-6-1166

52. Shirakawa S, Tsuchiya S, Tsutsumi Y et al (1998) Time course of saliva and serum melatonin levels after ingestion of melatonin. Psychiatry Clin Neurosci 52:266-267. https://doi. org/10.1111/j.1440-1819.1998.tb01067.x

53. Lemoine P, Nir T, Laudon M, Zisapel N (2007) Prolongedrelease melatonin improves sleep quality and morning alertness in insomnia patients aged 55 years and older and has no withdrawal effects. J Sleep Res 16:372-380. https://doi.org/10.111 1/j.1365-2869.2007.00613.x

54. Wade AG, Ford I, Crawford G et al (2007) Efficacy of prolonged release melatonin in insomnia patients aged 55-80 years: quality of sleep and next-day alertness outcomes. Curr Med Res Opin 23:2597-2605. https://doi.org/10.1185/030079907X233098

55. Ferracioli-Oda E, Qawasmi A, Bloch MH (2013) Meta-analysis: melatonin for the treatment of primary sleep disorders. PLoS ONE 8:e63773. https://doi.org/10.1371/journal.pone.0063773

56. Nogueira LM, Sampson JN, Chu LW et al (2013) Individual variations in serum melatonin levels through time: implications for epidemiologic studies. PLoS ONE 8:e83208. https://doi.org/10.1371/ journal.pone. 0083208

57. Skene DJ, Swaab DF (2003) Melatonin rhythmicity: effect of age and Alzheimer's disease. Exp Gerontol 38:199-206

58. Wu Y-H, Zhou J-N, Van Heerikhuize J et al (2007) Decreased MT1 melatonin receptor expression in the suprachiasmatic nucleus in aging and Alzheimer's disease. Neurobiol Aging 28:1239-1247. https://doi.org/10.1016/j.neurobiolaging.2006.06.002

59. Pandi-Perumal SR, Seils LK, Kayumov L et al (2002) Senescence, sleep, and circadian rhythms. Ageing Res Rev 1:559-604

60. Cerea G, Vaghi M, Ardizzoia A et al (2003) Biomodulation of cancer chemotherapy for metastatic colorectal cancer: a randomized study of weekly low-dose irinotecan alone versus irinotecan plus the oncostatic pineal hormone melatonin in metastatic colorectal cancer patients progressing on 5-fluorouracil-containing combinations. Anticancer Res 23:1951-1954

61. Innominato PF, Lim AS, Palesh O et al (2016) The effect of melatonin on sleep and quality of life in patients with advanced breast cancer. Support Care Cancer 24:1097-1105. https://doi. org/10.1007/s00520-015-2883-6

62. Madsen MT, Hansen MV, Andersen LT et al (2016) Effect of melatonin on sleep in the perioperative period after breast cancer surgery: a randomized, double-blind, placebo-controlled trial. J Clin Sleep Med 12:225-233. https://doi.org/10.5664/jcsm.5490

63. Lissoni P, Ardizzoia A, Barni S et al (1995) A randomized study of tamoxifen alone versus tamoxifen plus melatonin in estrogen receptor-negative heavily pretreated metastatic breast cancer patients. Oncol Rep 2:871-873

64. Hansen MV, Andersen LT, Madsen MT et al (2014) Effect of melatonin on depressive symptoms and anxiety in patients undergoing breast cancer surgery: a randomized, double-blind, placebocontrolled trial. Breast Cancer Res Treat 145:683-695. https://doi. org/10.1007/s10549-014-2962-2

65. Lissoni P, Barni S, Ardizzoia A et al (1992) Randomized study with the pineal hormone melatonin versus supportive care alone in advanced nonsmall cell lung cancer resistant to a first-line chemotherapy containing cisplatin. Oncology 49:336-339

66. Del Fabbro E, Dev R, Hui D et al (2013) Effects of melatonin on appetite and other symptoms in patients with advanced cancer and cachexia: a double-blind placebo-controlled trial. J Clin Oncol 31:1271-1276. https://doi.org/10.1200/JCO.2012.43.6766

67. Sookprasert A, Johns NP, Phunmanee A et al (2014) Melatonin in patients with cancer receiving chemotherapy: a randomized, double-blind, placebo-controlled trial. Anticancer Res 34:7327-7337

68. Vural EMS, Van Munster BC, de Rooij SE (2014) Optimal dosages for melatonin supplementation therapy in older adults: a systematic review of current literature. Drugs Aging 31:441-451. https://doi.org/10.1007/s40266-014-0178-0

Publisher's Note Springer Nature remains neutral with regard to jurisdictional claims in published maps and institutional affiliations. 